\title{
The Relationship Between Active and Passive Exposure to Cigarette Smoke and Severe Lumbar Intervertebral Disc Degeneration According to Demographic Data
}

\section{Demografik Verilere Göre Sigara Dumanına Aktif ve Pasif Maruziyet ile Ciddi Lomber İntervertebral Disk Dejenerasyonu Arasındaki İlişki}

\author{
(D) Fatma Esra Bahadır Ülger \\ Fatih Sultan Mehmet Training and Research Hospital, Clinic of Radiology, İstanbul, Turkey
}

\section{Abstract}

Objective: To investigate the effect of current, former and passive smoking status on degeneration of lumbar intervertebral discs.

Method: Three hundred and sixty patients between the ages of 20 and 70 years, who underwent lumbar spinal magnetic resonance imaging, were included in the study. The patients were grouped according to their smoking status as current, former, passive smokers and nonsmokers. The cumulative smoking dose for current and former smokers was calculated in terms of pack-years and categorized further into two subgroups: smoked $\leq 9$ pack-years or $>9$ pack-years. Patients who had been exposed to cigarette smoke for more than one year and more than one hour a day were included in the passive smoker group. The lumbar intervertebral discs were evaluated by the Pfirrmann disc degeneration grading system using sagittal T2-weighted magnetic resonance images. Grades IV and V were considered as "severe disc degeneration".

Results: There was a statistically significant difference between smoking status and gender, age, body mass index and lumbar lordosis angle $(p<0.05)$. There was a statistically significant difference between smoking status and the presence of severe disc degeneration at L1$2, L 2-3, L 5-S 1$ levels $(p<0.05)$. The rate of severe intervertebral disc degeneration was low at L1-2 (15\%) and gradually increased at other disc levels (L2-3: 20.3\%, L3-4: 28.3\%, L4-5: 47.2\%, L5- S1: 53.6\%). According to multivariate analysis, each unit increase in age was significantly associated with intervertebral disc degeneration at all levels $(p<0.05)$. Passive smoking was found to be significantly associated with L2-3 and L3-4 disc degeneration; and >9 pack-years current smoking was found to be significantly associated with L5-S1 disc degeneration $(p<0.05)$.

\section{Öz}

Amaç: Aktif, eski ve pasif sigara içme durumunun lomber intervertebral disklerin dejenerasyonuna etkisini araştırmaktır.

Yöntem: Çalışmaya lomber spinal manyetik rezonans görüntüleme yapılan 20-70 yaş aralığında olan 360 hasta dahil edildi. Hastalar sigara içme durumlarına göre aktif, eski, pasif içici ve içmeyen olarak gruplandırıldı. Aktif ve eski sigara içenler için kümülatif sigara dozu paket yılı cinsinden hesaplandı ve iki alt gruba ayrıldı: $\leq 9$ paketyıl veya >9 paket-yıl. Bir yıldan fazla ve günde bir saatten fazla sigara dumanına maruz kalan hastalar pasif içici grubuna dahil edildi. Lomber intervertebral diskler, sagital T2 ağırlıklı manyetik rezonans görüntüleri kullanılarak Pfirrmann disk dejenerasyon derecelendirme sistemi ile değerlendirildi. Grade IV ve V olarak tanımlanan diskler, "ciddi disk dejenerasyonu" olarak kabul edildi.

Bulgular: Sigara içme durumu ile cinsiyet, yaş, vücut kitle indeksi ve lomber lordoz açısı arasında istatistiksel olarak anlamlı bir fark vardı $(p<0,05)$. Sigara içme durumu ile L1-2, L2-3, L5-S1 seviyelerinde ciddi disk dejenerasyonu varlığı arasında istatistiksel olarak anlamlı fark vardı $(p<0,05)$. Ciddi intervertebral disk dejenerasyonu oranı L1-2'de (\%15) düşüktü ve diğer disk seviyelerinde kademeli olarak arttı (L2-3: \%20,3, L34: \%28,3, L4-5: \%47,2, L5- S1: \%53,6). Çok değişkenli analize göre, yaştaki her bir birim artı̧̧ tüm seviyelerde intervertebral disk dejenerasyonu ile anlamlı derecede ilişkiliydi $(p<0,05)$. Pasif içicilik L2-3 ve L3-4 disk dejenerasyonu ile anlamlı derecede ilişkili bulunurken, >9 paket-yıl aktif sigara içimi L5-S1 disk dejenerasyonu ile anlamlı derecede ilişkili bulundu $(p<0,05)$.

Address for Correspondence: Fatma Esra Bahadır Ülger, Fatih Sultan Mehmet Training and Research Hospital, Clinic of Radiology, İstanbul, Turkey E-mail: esrabahadir@hotmail.com ORCID: orcid.org/0000-0002-2431-1757 Received: 10.03.2021 Accepted: 21.05.2021

Cite this article as: Bahadır Ülger FE. The Relationship Between Active and Passive Exposure to Cigarette Smoke and Severe Lumbar Intervertebral Disc Degeneration According to Demographic Data. Bagcilar Med Bull 2021;6(3):220-228

(-) Copyright 2021 by the Health Sciences University Turkey, Bagcilar Training and Research Hospital Bagcilar Medical Bulletin published by Galenos Publishing House. 


\section{Abstract}

Conclusion: There is a significant relationship between passive smoking and severe disc degeneration at upper lumbar levels. Also it was thought that quitting smoking could reverse some of the negative effects associated with smoking contributing to disc degeneration.

Keywords: Current smoker, former smoker, intervertebral disc degeneration, magnetic resonance imaging, passive smoker, smoking

\section{Öz}

Sonuç: Üst lomber seviyelerde pasif sigara içimi ile ciddi disk dejenerasyonu arasında anlamlı bir ilişki vardır. Ayrıca sigarayı bırakmanın, disk dejenerasyonuna katkıda bulunan bazı sigara ile ilgili olumsuz etkileri tersine çevirebileceği düşünülmüştür.

Anahtar kelimeler: Aktif sigara içen, eski sigara içen, intervertebral disk dejenerasyonu, manyetik rezonans görüntüleme, pasif içicilik, sigara içme

\section{Introduction}

Besides normal aging, genetic and environmental factors are important potential determinants of lumbar disc degeneration. The effect and importance of heredity on disc degeneration has been shown in some twin studies (1-3). Acquired factors such as obesity, diabetes mellitus, smoking, physical loading and bone mineral density were found to be associated with disc degeneration in the literature (4). There are also studies investigating the relationship between atherosclerosis and disc degeneration. Disruption of the blood supply due to atherosclerosis contributes to the degeneration process (5-7). The association between lumbar disc degeneration/herniation and cardiovascular risk factors was also investigated by Hangai et al. (4) and Jhawar et al. (8) considering the relationship between atherosclerosis and cardiovascular risk factors.

Smoking causes serious health problems, particularly lung and other cancers, heart disease and respiratory diseases, and is among the most common causes of death worldwide $(9,10)$. These serious consequences of smoking affect not only smokers but also passive smokers (11). Besides these commonly known diseases related to smoking, numerous studies have shown that smoking has detrimental effects on the musculoskeletal system and worsens the prognosis and treatment of leukomotor diseases (12). Experimental studies investigating the association between smoking and disc degeneration have shown that the toxic effect of nicotine, increased degradation of collagen and disc malnutrition caused by decreased blood flow are the most accepted mechanisms explaining the disc degeneration process $(12,13)$.

In the literature, there are clinical (surgical and imaging) and experimental studies examining the effect of smoking status on disc degeneration (13). In some of the imaging studies, smoking was associated with disc degeneration and herniation (14-18), but the others did not find any relation (4,19-21). Only current smoker, former smoker and non-smoker groups were included in these studies. To the best of our knowledge, the effect of passive smoking on intervertebral disc degeneration in humans has not been investigated in previous studies. The aim of the study was to investigate the effect of current, former and passive smoking status on degeneration of lumbar intervertebral discs.

\section{Materials and Methods}

This retrospective study was performed by obtaining medical records of patients who underwent lumbar spinal magnetic resonance imaging (MRI) between September 2019 and February 2020. Patients with a history of spinal surgery or instrumentation, spinal fracture, trauma, congenital or acquired spinal deformity tumor or infection and those whose MRI data were unavailable were excluded from the study. After the application of exclusion criteria, 955 patients were determined between the specified dates. These patients were called by phone to be questioned about their smoking status, demographic data (weight and height) and whether they were working in heavy work and whether they were athletes (22). Heavy workers and athletes were also excluded from the study and a total of 360 patients whose smoking status information could be obtained were included in the study. The patients were grouped according to their smoking status which was assessed by self-report using following questions: "Have you ever smoked?", "Do you currently smoke?", "Have you been exposed to cigarette smoke from other smokers?". If a patient answered that he currently smoked, he was classified as "current smoker". If a patient answered that he had a history of smoking but not smoking currently, he was classified as "former smoker". If a patient answered that he did not currently smoke, did not have a history of smoking, and was not exposed to smoke, he was classified as "non-smoker". If a patient never smoked and never had a history of smoking, but exposed to cigarette smoke due to a family member or a colleague to a minimum of one hour every day for more than one year, he was classified as "passive smoker" $(11,23,24)$. The cumulative smoking dose for current and former smokers was calculated in terms of pack-years and categorized 
further into two subgroups: smoked $\leq 9$ pack-years or $>9$ pack-years (25). The number of pack-years was calculated by dividing the number of cigarettes consumed per day by 20 and multiplying by the years that the patient had smoked (19). Age and gender were recorded. Body mass index (BMI) was calculated as weight/ (height) ${ }^{2}$.

Lumbar spinal MRI was performed using a 1.5 Tesla imaging system (General Electric Healthcare, Milwaukee, WI), using the following settings: amplitude: $44 \mathrm{mT} / \mathrm{m}$; slew rate gradient configuration: $200 \mathrm{~T} / \mathrm{m} / \mathrm{s}$. MRI images were evaluated using a GE advantage workstation (GE Healthcare, Buc, France) and volume share software v.7.0. The lumbar lordosis angle was measured and the lumbar intervertebral discs were evaluated by the Pfirrmann disc degeneration grading system using sagittal T2-weighted MR images (TR/TE: 2500/85 ms, matrix: 320x224, slice thickness: 4 mm, FOV: 32) (26).

According to the Pfirrmann disc degeneration grading system, the degree of degeneration was classified into five grades. In accordance with the literature, grades IV and $\mathrm{V}$ were accepted as severe disc degeneration $(4,27)$. In this classification, grade IV identification is used for discs with inhomogeneous structures, where nucleus and annulus distinction cannot be made, with intermediate to hypointense signal intensity, normal or slightly decreased height. Grade V identification is used for discs with inhomogeneous structures, where nucleus and annulus distinction cannot be made, with hypointense signal intensity, collapsed disc space (Figure 1). We accepted the dependent variable in logistic regression as patients with severe disc degeneration. When evaluating the factors affecting severe disc degeneration, the non-smoker group was considered as a reference and the effect of other smoking status on severe disc degeneration compared to non-smokers was examined.

MRI evaluations were made by the same experienced radiologist who was blinded to the smoking status of the participants. The Institutional Review Board approved the study protocol (24.02.2020-17073117-050.06-E.65) Informed consent for lumbar spinal MRI was obtained from all individual participants included in the study.

\section{Statistical Analysis}

Statistical analysis was performed using IBM SPSS Statistics for Windows v.21.0 (IBM Corp., Armonk, NY, USA). Frequency and percentage for discrete data, mean \pm standard deviation and median for continuous data were given as descriptive values. The "ANOVA test" was used for comparing the means between the groups and comparing the means of more than two groups. The "Logistic Regression Analysis" was used to evaluate the severe disc degeneration at each lumbar level. Results were considered statistically significant when $\mathrm{p}$-value was less than 0.05 .

\section{Results}

The mean age of the participants was $47.17 \pm 12.65$ years (range: 20-70 years). Among the 360 participants, 134 were male $(37.2 \%)$ and 226 were female $(62.8 \%)$. The mean BMI of the participants was $27.40 \pm 4.92 \mathrm{~kg} / \mathrm{m}^{2}$ (range: $15.9-47.8$ $\mathrm{kg} / \mathrm{m}^{2}$ ), and the mean lordosis angle of the participants was $42.69 \pm 12.90^{\circ}$ (range: 9.8-82.5 ${ }^{\circ}$. The rate of severe intervertebral disc degeneration was $15 \%$ at L1-2, $20.3 \%$ at L2-3, 28.3\% at L3-4, $47.2 \%$ at L4-5, and 53.6\% at L5-S1 disc level (Table 1).

Distributions of demographic variables according to smoking status are given in Table 2. There was a statistically significant difference between smoking status and gender, age, BMI and lumbar lordosis angle $(\mathrm{p}<0.05)$. The vast majority of passive smokers were women, and former smokers had the highest values in terms of age and BMI.

Distributions of severe disc degeneration at lumbar intervertebral disc levels according to smoking status

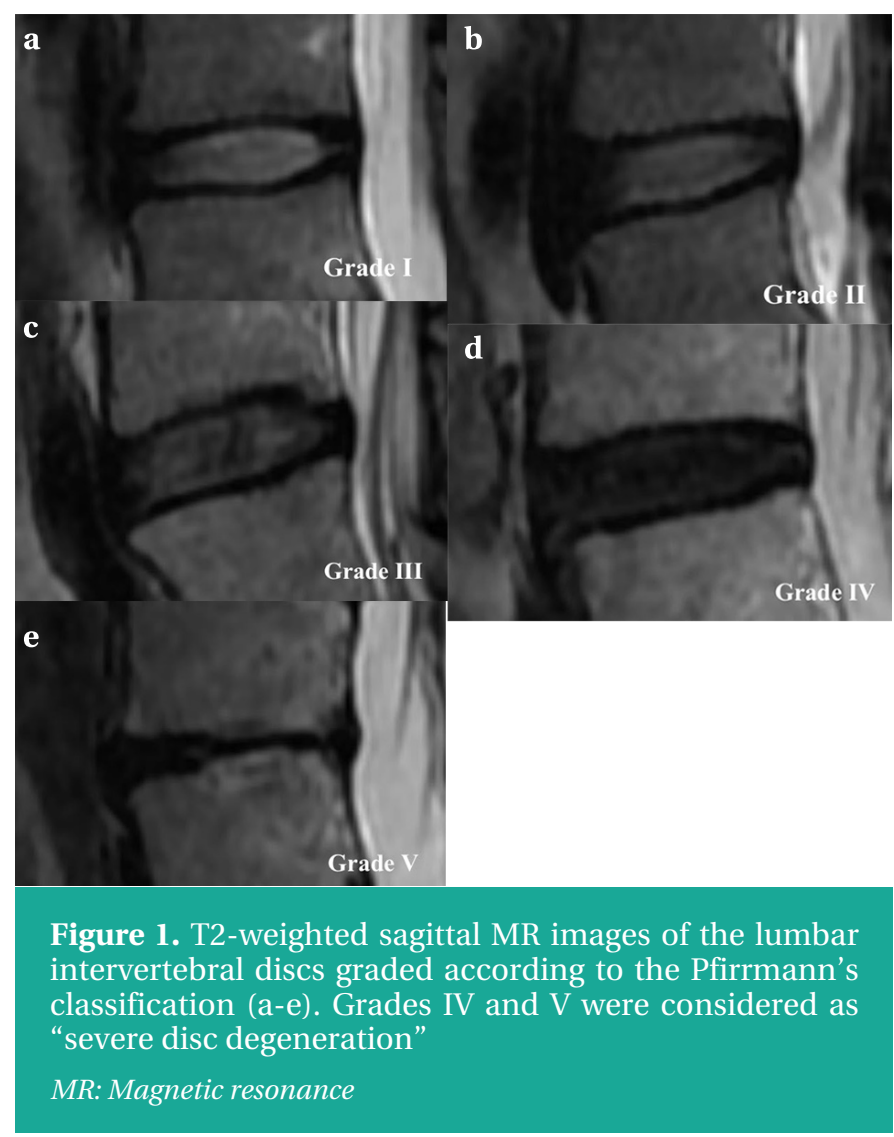


are given in Table 3. There was a statistically significant difference between smoking status and the presence of severe disc degeneration at L1-2, L2-3, L5-S1 levels ( $\mathrm{p}<0.05)$. It was determined that severe disc degeneration at the L1-2 level was mostly in the passive and $>9$ pack/year former smoker groups. At the L2-3 level, severe disc degeneration was found mostly in the passive smoker group. At the L5S1 level, the most severe disc degeneration was detected in the $>9 \mathrm{pack} / \mathrm{year}$ current smoker group. There was no statistically significant difference between smoking status and the presence of severe disc degeneration at L3-4, L4-5 levels.

\begin{tabular}{|c|c|c|c|c|c|}
\hline \multirow[b]{2}{*}{ Variables } & \multicolumn{3}{|c|}{ Total } & \multicolumn{2}{|c|}{$\begin{array}{l}\text { By } \\
\text { category }\end{array}$} \\
\hline & $\mathbf{N}$ & Mean & SD & $\mathbf{N}$ & $\%$ \\
\hline Age & 360 & 47.17 & 12.646 & - & - \\
\hline BMI & 360 & 27.40 & 4.924 & - & - \\
\hline Gender & 360 & - & - & - & - \\
\hline Male & - & - & - & 134 & 37.2 \\
\hline Female & - & - & - & 226 & 62.8 \\
\hline Smoking status & 360 & - & - & & \\
\hline $\begin{array}{l}\text { Current smoker } \leq 9 \text { pack/ } \\
\text { year }\end{array}$ & - & - & - & 49 & 13.6 \\
\hline $\begin{array}{l}\text { Current smoker }>9 \text { pack/ } \\
\text { year }\end{array}$ & - & - & - & 79 & 21.9 \\
\hline Passive smoker & - & - & - & 77 & 21.4 \\
\hline Non-smoker & - & - & - & 96 & 26.7 \\
\hline $\begin{array}{l}\text { Former smoker } \leq 9 \text { pack/ } \\
\text { year }\end{array}$ & - & - & - & 25 & 6.9 \\
\hline $\begin{array}{l}\text { Former smoker }>9 \text { pack/ } \\
\text { year }\end{array}$ & - & - & - & 34 & 9.4 \\
\hline Lordosis angle & 360 & 42.69 & 12.897 & - & - \\
\hline L1-2 & 360 & 2.03 & 1.16 & - & - \\
\hline $\begin{array}{l}\text { Severe disc degeneration } \\
\text { (grade 4-5) }\end{array}$ & - & - & - & 54 & 15 \\
\hline L2-3 & 360 & 2.26 & 1.244 & - & - \\
\hline $\begin{array}{l}\text { Severe disc degeneration } \\
\text { (grade 4-5) }\end{array}$ & - & - & - & 73 & 20.3 \\
\hline L3-4 & 360 & 2.57 & 1.28 & - & - \\
\hline $\begin{array}{l}\text { Severe disc degeneration } \\
\text { (grade 4-5) }\end{array}$ & - & - & - & 102 & 28.3 \\
\hline L4-5 & 360 & 3.14 & 1.234 & - & - \\
\hline $\begin{array}{l}\text { Severe disc degeneration } \\
\text { (grade 4-5) }\end{array}$ & - & - & - & 170 & 47.2 \\
\hline L5-S1 & 360 & 3.34 & 1.325 & - & - \\
\hline $\begin{array}{l}\text { Severe disc degeneration } \\
\text { (grade 4-5) }\end{array}$ & - & - & - & 193 & 53.6 \\
\hline
\end{tabular}

BMI: Body mass index, SD: Standard deviation
The results of univariate and multivariate analysis examining the relationship between demographic data and smoking status in terms of severe lumbar disc degeneration are given in Table 4 and 5. In univariate analysis, age, BMI and $>9$ pack/ year former smokers were found statistically significant in terms of disc degeneration at L1-2 and L4-5 disc levels; age, BMI, lordosis angle and passive smokers were found statistically significant in terms of disc degeneration at L2-3 and L3-4 disc levels; age, lordosis angle, $>9$ pack/year current smokers, $\leq 9$ pack/year former smokers, and $>9$ pack/ year former smokers were found statistically significant in terms of disc degeneration at L5-S1 disc level $(\mathrm{p}<0.05)$. For example, at L1-2 disc level for every 1 year increase in age, L1-2 disc degeneration increased 1.15 times, for every 1 unit change in BMI L1-2 disc degeneration increased 1.10 times, and former smokers had L1-2 disc degeneration 5.16 times more than non-smokers (Table 4).

According to multivariate analysis, age, and BMI were found statistically significant in terms of disc degeneration at L1-2 and L4-5 disc levels; age, and passive smokers were found statistically significant in terms of disc degeneration at L2-3 disc levels; age, BMI and passive smokers were found statistically significant in terms of disc degeneration at L3-4 disc levels; age, lordosis angle, and >9 pack/year current smokers were found statistically significant in terms of disc degeneration at L5-S1 disc levels $(\mathrm{p}<0.05)$. For instance, at L1-2 disc level for every 1 year increase in age, L1-2 disc degeneration increased 1.16 times, for every 1 unit change in BMI L1-2 disc degeneration increased 1.07 times. According to multivariate analysis gender, $\leq 9$ pack/ year current smoker, $\leq 9$ pack/year former smoker and $>9$ pack/year former smoker were not associated with disc degeneration at any level (Table 5).

\section{Discussion}

In the present study, the rate of severe intervertebral disc degeneration was low at L1-2 (15\%), and increased gradually at more inferior intervertebral disc levels (L2-3: 20.3\%, L3-4: 28.3\%, L4-5: 47.2\%, L5-S1: 53.6\%) (Table 1). The vast majority of passive smokers were women, and former smokers had the highest values in terms of age and BMI. According to multivariate analysis, each unit increase in age was significantly associated with intervertebral disc degeneration at all levels $(\mathrm{p}<0.05)$. Passive smoking was found to be significantly associated with L2-3 and L3-4 disc degeneration, and $>9$ pack-years current smoking was found to be significantly associated with L5-S1 disc degeneration $(\mathrm{p}<0.05)$ (Table 5). 
Table 2. Distribution of demographic variables according to smoking status

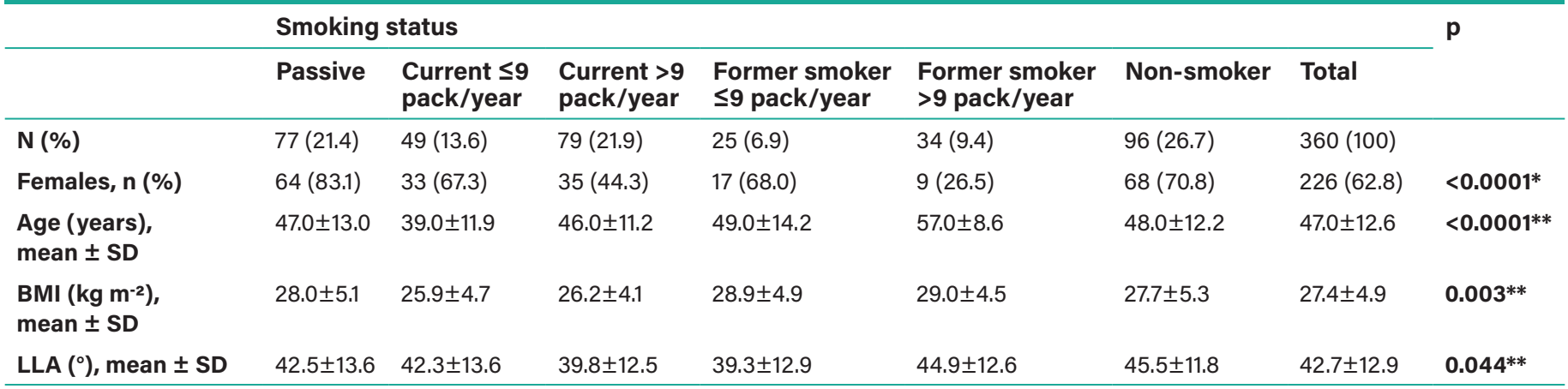

BMI: Body mass index, LLA: Lumbar lordosis angle, SD: Standard deviation, ${ }^{*}$ chi-square test, ${ }^{* * A N O V A}$ test

Table 3. Distribution of severe disc degeneration at lumbar intervertebral disc levels according to smoking status

Smoking status

p*

\begin{tabular}{|c|c|c|c|c|c|c|c|c|}
\hline $\begin{array}{l}\text { Severe disc } \\
\text { degeneration at } \\
\text { lumbar disc levels }\end{array}$ & Passive & $\begin{array}{l}\text { Current } \leq 9 \\
\text { pack/year }\end{array}$ & $\begin{array}{l}\text { Current }>9 \\
\text { pack/year }\end{array}$ & $\begin{array}{l}\text { Former smoker } \\
\leq 9 \mathrm{pack} / \text { year }\end{array}$ & $\begin{array}{l}\text { Former smoker } \\
>9 \text { pack/year }\end{array}$ & Non- smoker & Total & \\
\hline P L1-2, n (\%) & $12(22.2)$ & $5(9.3)$ & $11(20.4)$ & $3(5.6)$ & $12(22.2)$ & $11(20.4)$ & $54(100)$ & 0.023 \\
\hline P L3-4, n (\%) & $30(29.4)$ & $10(9.8)$ & $18(17.6)$ & $9(8.8)$ & $13(12.7)$ & $22(21.6)$ & $102(100)$ & 0.057 \\
\hline P L4-5, n (\%) & $42(24.7)$ & $21(12.4)$ & $35(20.6)$ & $14(8.2)$ & $20(11.8)$ & $38(22.4)$ & $170(100)$ & 0.209 \\
\hline
\end{tabular}

P Pfirmann grade, ${ }^{*}$ chi-square test

Considering the socioeconomic burden caused by low back pain due to intervertebral disc degeneration in societies, it can be understood that a great interest was paid on the investigation of the factors in the etiology of disc degeneration (28). Various factors such as age, mechanical factors, genetics, nutrition, metabolic disorders, infection, and toxic factors like nicotine have been found to have detrimental effects on intervertebral discs (22).

In addition to the negative effects of smoking on the lung and cardiovascular system, the harmful effects of smoking on the musculoskeletal system have also been the subject of research $(12,23)$. Studies on this issue have shown that smoking delays fracture healing, decreases bone mineral density, increases fracture risk, and causes bone graft nonunion in spinal fusion surgeries (29). Another area of interest in this subject is the effect of smoking on intervertebral disc degeneration. Disc malnutrition, caused by both tobaccoinduced anoxia and vascular disease and the direct effects of chemical substances on disc cell viability are the most accepted mechanisms that explain smoking related disc degeneration $(13,28)$. In addition, chronic cough, which is common in smokers, can cause an increase in intradiscal pressure and mechanically induce degeneration negatively (30).
In the literature, there are studies showing the negative effect of smoking on lumbar disc degeneration, as well as others with different results. Battié et al. (14) found that smokers had $18 \%$ greater mean disc degeneration scores in the lumbar spine compared to non-smokers in a population consisting of identical twins. Jakoi et al. (28) reported a strong correlation between lumbar disc degenerative disease and tobacco use. They found a nearly 6 -fold increase in the prevalence of smokers' lumbar disc degenerative disease compared to non-smokers. In a systematic review, Huang et al. (31) reported that current smokers showed a higher risk of developing lumbar disc herniation than former smokers and both male and female smokers had a similar risk of lumbar disc herniation. Schumann et al. (32) concluded that smoking 20-40 pack/years significantly increased the rate of lumbar disc herniation in men and smoking 8-20 packs/ year increased the risk of lumbar disc herniation in women. Livshits et al. (15) found that smoking showed statistically significant relationships with risk of disc herniation. On the other hand, there have been studies that found opposing results. Hangai et al. (4) could not find a correlation between smoking and disc degeneration in their study. However, they thought that this might be due to the insufficient number of patients who actively smoked (4). Kuisma et al. (19) reported that smoking was not significantly associated 
Table 4. Univariate analysis for severe disc degeneration at lumbar intervertebral disc levels

\begin{tabular}{|c|c|c|c|c|c|c|c|c|c|c|}
\hline \multirow{2}{*}{$\begin{array}{l}\text { Univariate } \\
\text { analysis* }\end{array}$} & \multicolumn{2}{|l|}{ P L1-2 } & \multicolumn{2}{|l|}{ P L2-3 } & \multicolumn{2}{|l|}{ P L3-4 } & \multicolumn{2}{|l|}{ P L4-5 } & \multicolumn{2}{|l|}{ P L5-S1 } \\
\hline & $\begin{array}{l}\text { OR } \\
(95 \% \mathrm{Cl})\end{array}$ & $\mathbf{p}$ & $\begin{array}{l}\text { OR } \\
(95 \% \mathrm{Cl})\end{array}$ & $\mathbf{p}$ & $\begin{array}{l}\text { OR } \\
(95 \% \mathrm{Cl})\end{array}$ & $\mathbf{p}$ & $\begin{array}{l}\text { OR } \\
\text { (95\% Cl) }\end{array}$ & p & $\begin{array}{l}\text { OR } \\
(95 \% \mathrm{Cl})\end{array}$ & p \\
\hline Age & $\begin{array}{l}1.15 \\
(1.10-1.19)\end{array}$ & $<0.0001$ & $\begin{array}{l}1.15 \\
(1.11-1.19)\end{array}$ & $<0.0001$ & $\begin{array}{l}1.12 \\
(1.09-1.15)\end{array}$ & $<0.0001$ & $\begin{array}{l}1.08 \\
(1.06-1.10)\end{array}$ & $<0.0001$ & $\begin{array}{l}1.07 \\
(1.05-1.09)\end{array}$ & $<0.0001$ \\
\hline Female & $\begin{array}{l}1.01 \\
(0.55-1.84)\end{array}$ & 0.976 & $\begin{array}{l}1.75 \\
(0.99-3.07)\end{array}$ & 0.054 & $\begin{array}{l}1.34 \\
(0.83-2.18)\end{array}$ & 0.230 & $\begin{array}{l}1.42 \\
(0.92-2.18)\end{array}$ & 0.113 & $\begin{array}{l}1.11 \\
(0.72-1.70)\end{array}$ & 0.637 \\
\hline BMI & $\begin{array}{l}1.10 \\
(1.04-1.16)\end{array}$ & 0.001 & $\begin{array}{l}1.08 \\
(1.03-1.14)\end{array}$ & 0.003 & $\begin{array}{l}1.15 \\
(1.09-1.21)\end{array}$ & $<0.0001$ & $\begin{array}{l}1.12 \\
(1.06-1.17)\end{array}$ & $<0.0001$ & $\begin{array}{l}1.02 \\
(0.97-1.06)\end{array}$ & 0.368 \\
\hline LLA & $\begin{array}{l}1.02 \\
(1.00-1.04)\end{array}$ & 0.116 & $\begin{array}{l}1.02 \\
(1.00-1.04)\end{array}$ & 0.027 & $\begin{array}{l}1.02 \\
(1.0-1.04)\end{array}$ & 0.024 & $\begin{array}{l}1.01 \\
(0.99-1.03)\end{array}$ & 0.140 & $\begin{array}{l}1.02 \\
(1.01-1.04)\end{array}$ & 0.005 \\
\hline \multicolumn{11}{|c|}{ Smoking status } \\
\hline Non-smoker & 1.0 & - & 1.0 & - & 1.0 & - & 1.0 & - & 1.0 & - \\
\hline Current $\leq 9$ & $\begin{array}{l}1.30 \\
(0.38-4.22)\end{array}$ & 0.719 & $\begin{array}{l}1.68 \\
(0.58-4.90)\end{array}$ & 0.343 & $\begin{array}{l}1.16 \\
(0.49-2.83)\end{array}$ & 0.707 & $\begin{array}{l}1.13 \\
(0.56-2.29)\end{array}$ & 0.734 & $\begin{array}{l}1.04 \\
(0.51-2.10)\end{array}$ & 0.920 \\
\hline Current $>9$ & $\begin{array}{l}1.21 \\
(0.48-3.07)\end{array}$ & 0.687 & $\begin{array}{l}1.15 \\
(0.51-2.60)\end{array}$ & 0.737 & $\begin{array}{l}1.02 \\
(0.50-2.08)\end{array}$ & 0.956 & $\begin{array}{l}1.16 \\
(0.64-2.12)\end{array}$ & 0.625 & $\begin{array}{l}2.80 \\
(1.51-5.18)\end{array}$ & 0.001 \\
\hline Passive & $\begin{array}{l}1.93 \\
(0.81-4.56)\end{array}$ & 0.136 & $\begin{array}{l}2.07 \\
(1.01-4.24)\end{array}$ & 0.047 & $\begin{array}{l}2.41 \\
(1.25-4.63)\end{array}$ & 0.009 & $\begin{array}{l}1.68 \\
(0.93-3.05)\end{array}$ & 0.087 & $\begin{array}{l}1.54 \\
(0.85-2.80)\end{array}$ & 0.152 \\
\hline Former $\leq 9$ & $\begin{array}{l}1.36 \\
(0.34-5.41)\end{array}$ & 0.665 & $\begin{array}{l}1.88 \\
(0.64-5.53)\end{array}$ & 0.254 & $\begin{array}{l}2.47 \\
(0.93-6.58)\end{array}$ & 0.070 & $\begin{array}{l}1.83 \\
(0.72-4.66)\end{array}$ & 0.204 & $\begin{array}{l}3.00 \\
(1.12-8.03)\end{array}$ & 0.029 \\
\hline Former $>9$ & $\begin{array}{l}5.16 \\
(1.96-13.61)\end{array}$ & 0.001 & $\begin{array}{l}2.27 \\
(0.91-5.70)\end{array}$ & 0.080 & $\begin{array}{l}2.14 \\
(0.90-5.08)\end{array}$ & 0.084 & $\begin{array}{l}3.36 \\
(1.43-7.87)\end{array}$ & 0.005 & $\begin{array}{l}2.67 \\
(1.16-6.16)\end{array}$ & 0.021 \\
\hline
\end{tabular}

BMI: Body mass index, LLA: Lumbar lordosis angle, P Pfirrman grade, *Logistic Regression Analysis, Cl: Confidence interval, OR: Odds ratio

\section{Table 5. Multivariate analysis for severe disc degeneration at lumbar intervertebral disc levels}

\begin{tabular}{|c|c|c|c|c|c|c|c|c|c|c|}
\hline $\begin{array}{l}\text { Multivariate } \\
\text { analysis* }\end{array}$ & \multicolumn{2}{|l|}{ P L1-2 } & \multicolumn{2}{|l|}{ P L2-3 } & \multicolumn{2}{|l|}{ P L3-4 } & \multicolumn{2}{|l|}{ P L4-5 } & \multicolumn{2}{|l|}{ P L5-S1 } \\
\hline Female & $\begin{array}{l}1.16 \\
(0.50-2.21)\end{array}$ & 0.704 & $\begin{array}{l}2.14 \\
(1.08-4.62)\end{array}$ & 0.043 & $\begin{array}{l}1.12 \\
(0.65-2.30)\end{array}$ & 0.719 & $\begin{array}{l}1.55 \\
(0.92-2.62)\end{array}$ & 0.099 & $\begin{array}{l}1.40 \\
(0.82-2.39)\end{array}$ & 0.219 \\
\hline LLA & $\begin{array}{l}1.01 \\
(0.98-1.04)\end{array}$ & 0.613 & $\begin{array}{l}1.01 \\
(0.98-1.03)\end{array}$ & 0.656 & $\begin{array}{l}1.01 \\
(0.98-1.03)\end{array}$ & 0.813 & $\begin{array}{l}1.01 \\
(0.99-1.03)\end{array}$ & 0.504 & $\begin{array}{l}1.04 \\
(1.03-1.07)\end{array}$ & $<0.0001$ \\
\hline \multicolumn{11}{|c|}{ Smoking status } \\
\hline Non-smoker & 1.0 & - & 1.0 & - & 1.0 & - & 1.0 & - & 1.0 & - \\
\hline Passive & $\begin{array}{l}2.35 \\
(0.88-6.27)\end{array}$ & 0.088 & $\begin{array}{l}2.82 \\
(1.17-6.80)\end{array}$ & 0.021 & $\begin{array}{l}3.42 \\
(1.53-7.67)\end{array}$ & 0.003 & $\begin{array}{l}1.81 \\
(0.92-3.55)\end{array}$ & 0.087 & $\begin{array}{l}1.54 \\
(0.79-3.01)\end{array}$ & 0.210 \\
\hline Former $\leq 9$ & $\begin{array}{l}1.09 \\
(0.23-5.24)\end{array}$ & 0.910 & $\begin{array}{l}1.48 \\
(0.40-5.59)\end{array}$ & 0.558 & $\begin{array}{l}2.54 \\
(0.74-8.70)\end{array}$ & 0.137 & $\begin{array}{l}1.58 \\
(0.55-4.51)\end{array}$ & 0.394 & $\begin{array}{l}2.52 \\
(0.86-7.41)\end{array}$ & 0.093 \\
\hline Former $>9$ & $\begin{array}{l}3.01 \\
(0.97-9.37)\end{array}$ & 0.057 & $\begin{array}{l}1.33 \\
(0.45-3.97)\end{array}$ & 0.605 & $\begin{array}{l}1.01 \\
(0.36-2.80)\end{array}$ & 0.982 & $\begin{array}{l}2.13 \\
(0.83-5.47)\end{array}$ & 0.115 & $\begin{array}{l}1.46 \\
(0.58-3.68)\end{array}$ & 0.423 \\
\hline
\end{tabular}

BMI: Body mass index, LLA: Lumbar lordosis angle, P Pfirrman grade, *Logistic Regression Analysis, Cl: Confidence interval, OR: Odds ratio 
with severe disc degeneration in a population consisting of middle-aged male workers. Kanayama et al. (20) concluded that smoking status was not a significant risk factor for the prevalence of disc degeneration and herniation. Schistad et al. (33) found that smoking status had no significant impact on 5-year disc degeneration development.

As mentioned above, numerous studies in the literature have found results that current smokers and former smokers have increased the risk of intervertebral disc degeneration. The effect of passive smoking, another subgroup in terms of exposure to smoking, on disc degeneration has been investigated in experimental studies using animal models (34-36). However, as far as we know, there is no study investigating the relationship between passive smoking and intervertebral disc degeneration in humans.

Passive smoking poses a considerable risk of associated diseases compared to active smokers, and the serious consequences of smoking affect not only smokers but also passive smokers $(37,38)$. Smoking is blamed for an estimated 480,320 deaths per year in the United States, of which 41.280 are due to lung cancer and coronary heart disease in individuals exposed to passive smoking (39). Considering the systemic proposed mechanisms of smoking on disc degeneration, the relationship between passive smoking and lumbar disc degeneration was also aimed to be investigated in this study.

Mechanical stress due to physical loading is expected to cause degeneration at lower lumbar levels (14). Since the effect of smoking is systemic, as previously described, it may cause higher degeneration grades in the upper and/ or lower lumbar levels. Saberi et al. (17) found that after eliminating the effect of other factors, cigarette smoking was associated with nucleus pulposus dislodgement only in upper lumbar levels $(\mathrm{p}=0.038)$. According to the results of this study, the significant relationship between disc degeneration at the upper (L2-3 and L3-4) lumbar levels and passive smoking suggests that passive smoking may cause more degeneration in the upper lumbar levels than mechanical stress.

Another remarkable topic from the results of the studies in the literature is whether there is a change in the degeneration findings after quitting smoking. In a review by Huang et al. (31), it was found that current smokers had a higher risk of developing lumbar disc herniation compared to former smokers. In an experimental study, Nemoto et al. (34) found that intervertebral disc degeneration due to smoking could be repaired to some extent after quitting smoking.
While investigating the relationship between smoking and surgical disc disease in their study, An et al. (40) stated that smoking cessation might have beneficial effects since there was no significant difference between former smokers and non-smokers. One of the results of the large-scale study by Knuttson et al. (41) was that quitting smoking reduced surgery. In the present study, when the current smokers and former smokers were compared in terms of severe disc degeneration, although current smoker's age and BMI were lower, $>9$ pack/year current smokers were found statistically significant in terms of disc degeneration at L5-S1 disc levels according to multivariate analysis. This result is thought to be a supportive finding that some of the negative effects of smoking may be reversed after quitting smoking.

\section{Study Limitations}

The present study has some limitations. Although those who did heavy physical work and athletes were excluded from the study, one of the limitations was that the subjects were not evaluated in terms of other risk factors that might cause lumbar disc degeneration, such as family history, daily physical activity and habits (long-term sitting, poor posture, alcohol use, etc.), diabetes and cardiovascular diseases, and musculoskeletal system diseases that increased the burden on the lumbar region. However, this was a retrospective study and it was not possible to retrospectively collect accurate information about the patient's daily activities and habits of previous days and other risk factors. Self-reporting on smoking status and smoking exposure may have led to misclassification of patients. However, self-questionnaire has been used in studies on this subject in the literature. Studies that are confident about the amount of exposure to smoking may only be available in experimental studies with animal models or in prospective studies.

\section{Conclusion}

Breathing cigarette smoke can systemically affect many organs/parts of the body negatively regardless of active smoking. Based on the significant relationship found between passive smoking and intervertebral disc degeneration at upper lumbar levels, which are less affected by mechanical factors, it has been considered as a finding supporting that cigarette smoke exposure may have an effect on disc degeneration. The study supports the view that some negative effects on disc degeneration may be reversible after smoking cessation. The longer we stay away from smoking or its smoke, the more we keep a preventable risk factor for disc degeneration away from our lives. 


\section{Acknowledgments}

The author acknowledges Cem Sener for his support on statistical analysis.

\section{Ethics}

Ethics Committee Approval: The Institutional Review Board of Fatih Sultan Mehmet Training and Research Hospital, İstanbul, approved the study protocol on February $24,2020$.

Informed Consent: Informed consent for lumbar spinal MRI was obtained from all individual participants included in the study.

Peer-review: Externally peer-reviewed.

Financial Disclosure: The author declared that this study has received no financial support.

\section{References}

1. Battie MC, Videman T, Parent E. Lumbar disc degeneration: epidemiology and genetic influences. Spine 2004;29(23):26792690.

2. Battie MC, Videman T, Gibbons LE, Fisher LD, Manninen H, Gill K. 1995 Volvo Award in clinical sciences. Determinants of lumbar disc degeneration. A study relating lifetime exposures and magnetic resonance imaging findings in identical twins. Spine 1995;20(24):2601-2612.

3. Sambrook PN, MacGregor AJ, Spector TD. Genetic influences on cervical and lumbar disc degeneration: a magnetic resonance imaging study in twins. Arthritis Rheum 1999;42(2):366-372.

4. Hangai M, Kaneoka K, Kuno S, Hinotsu S, Sakane M, Mamizuka $\mathrm{N}$, et al. Factors associated with lumbar intervertebral disc degeneration in the elderly. Spine J 2008;8(5):732-740.

5. Kauppila LI, McAlindon T, Evans S, Wilson PW, Kiel D, Felson DT. Disc degeneration/back pain and calcification of the abdominal aorta. A 25-year follow-up study in Framingham. Spine 1997;22:1642-1647; discussion 1648-1649.

6. Kauppila LI, Penttila A, Karhunen PJ, Lalu K, Hannikainen P. Lumbar disc degeneration and atherosclerosis of the abdominal aorta. Spine 1994;19(8):923-929.

7. Kurunlahti M, Kerttula L, Jauhiainen J, Karppinen J, Tervonen O. Correlation of diffusion in lumbar intervertebral disks with occlusion of lumbar arteries: a study in adult volunteers. Radiology 2001;221(3):779-786.

8. Jhawar BS, Fuchs CS, Colditz GA, Stampfer MJ. Cardiovascular risk factors for physician-diagnosed lumbar disc herniation. Spine J 2006;6(6):684-691.

9. Elmasry S, Asfour S, de Rivero Vaccari JP, Travascio F. Effects of tobacco smoking on the degeneration of the intervertebral disc: a finite element study. PLoS One 2015;10(8):e0136137. doi:10.1371/ journal.pone.0136137

10. WHO Report on the Global Tobacco Epidemic, 2017 external icon. Geneva: World Health Organization, 2017 Last Accessed Date: 31.01.2019. Available from: https://apps.who.int/iris/bitstream/ handle/10665/255874/9789241512824-eng.pdf?sequence $=1$
11. Nondahl DM, Cruickshanks KJ, Schubert CR. A questionnaire for assessing environmental tobacco smoke exposure. Environ Res 2005;97(1):76-82.

12. Abate M, Vanni D, Pantalone A, Salini V. Cigarette smoking and musculoskeletal disorders. Muscles Ligaments Tendons J 2013;3(2):63-69.

13. Jackson AR, Dhawale AA, Brown MD. Association between intervertebral disc degeneration and cigarette smoking: clinical and experimental findings. JBJS Rev 2015;3(3):01874474201503030-00002. doi: 10.2106/JBJS.RVW.N.00057.

14. Battié MC, Videman T, Gill K, Moneta GB, Nyman R, Kaprio J, et al. 1991 Volvo Award in clinical sciences. Smoking and lumbar intervertebral disc degeneration: an MRI study of identical twins. Spine (Phila Pa 1976) 1991;16(9):1015-1021.

15. Livshits G, Cohen Z, Higla O, Yakovenko K. Familial history, age and smoking are important risk factors for disc degeneration disease in Arabic pedigrees. Eur J Epidemiol 2001;17(7):643-651.

16. Videman T, Battié MC, Parent E, Gibbons LE, Vainio P, Kaprio J. Progression and determinants of quantitative magnetic resonance imaging measures of lumbar disc degeneration: a five-year follow-up of adult male monozygotic twins. Spine (Phila Pa 1976) 2008;33(13):1484-1490.

17. Saberi H, Rahimi L, Jahani L. A comparative MRI study of upper and lower lumbar motion segments in patients with low back pain. J Spinal Disord Tech 2009;22(7):507-510.

18. Matsumoto M, Okada E, Ichihara D, Watanabe $\mathrm{K}$, Chiba $\mathrm{K}$, Toyama Y, et al. Age-related changes of thoracic and cervical intervertebral discs in asymptomatic subjects. Spine (Phila Pa 1976) 2010;35(14):1359-1364.

19. Kuisma M, Karppinen J, Haapea M, Niinimäki J, Ojala R, Heliövaara $\mathrm{M}$, et al. Are the determinants of vertebral endplate changes and severe disc degeneration in the lumbar spine the same? A magnetic resonance imaging study in middle-aged male workers. BMC Musculoskelet Disord 2008;9:51.

20. Kanayama M, Togawa D, Takahashi C, Terai T, Hashimoto T. Cross-sectional magnetic resonance imaging study of lumbar disc degeneration in 200 healthy individuals. J Neurosurg Spine 2009;11(4):501-507.

21. Okada E, Matsumoto M, Ichihara D, Chiba K, Toyama Y, Fujiwara $\mathrm{H}$, et al. Aging of the cervical spine in healthy volunteers: a 10-year longitudinal magnetic resonance imaging study. Spine (Phila $\mathrm{Pa}$ 1976) 2009;34(7):706-712.

22. Sharma MK, Petrukhina E. Strong association of smoking with lumbar degenerative spine disease. Open Neurosurg J 2013;6:6-12.

23. Jhee JH, Joo YS, Kee YK, Jung SY, Park S, Yoon CY, et al. Secondhand Smoke and CKD. Clin J Am Soc Nephrol 2019;14(4):515-522.

24. Abrahamsen R, Fell AK, Svendsen MV, Andersson E, Torén K, Henneberger PK, et al. Association of respiratory symptoms and asthma with occupational exposures: findings from a populationbased cross-sectional survey in Telemark, Norway. BMJ Open 2017;7(3):e014018. doi: 10.1136/bmjopen-2016-014018.

25. Kaila-Kangas L, Leino-Arjas P, Riihimäki H, Luukkonen R, Kirjonen J. Smoking and overweight as predictors of hospitalization for back disorders. Spine (Phila Pa 1976) 2003;28(16):1860-1868.

26. Pfirrmann CW, Metzdorf A, Zanetti M, Hodler J, Boos N. Magnetic resonance classification of lumbar intervertebral disc degeneration. Spine (Phila Pa 1976) 2001;26(17):1873-1878. 
27. Teichtahl AJ, Urquhart DM, Wang Y, Wluka AE, O'Sullivan R, Jones $\mathrm{G}$, et al. Lumbar disc degeneration is associated with modic change and high paraspinal fat content - a 3.0T magnetic resonance imaging study. BMC Musculoskelet Disord 2016;17(1):439.

28. Jakoi AM, Pannu G, D'Oro A, Buser Z, Pham MH, Patel NN, et al. The Clinical Correlations between Diabetes, Cigarette Smoking and Obesity on Intervertebral Degenerative Disc Disease of the Lumbar Spine. Asian Spine J 2017;11(3):337-347.

29. Sloan A, Hussain I, Maqsood M, Eremin O, El-Sheemy M. The effects of smoking on fracture healing. Surgeon 2010;8(2):111-116.

30. Frymoyer JW, Pope MH, Costanza MC, Rosen JC, Goggin JE, Wilder DG. Epidemiologic studies of low-back pain. Spine 1980;5:419-423.

31. Huang W, Qian Y, Zheng K, Yu L, Yu X. Is smoking a risk factor for lumbar disc herniation? Eur Spine J 2016;25:168-176.

32. Schumann B, Bolm-Audorff U, Bergmann A, Ellegast R, Elsner G, Grifka J, et al. Lifestyle factors and lumbar disc disease: results of a German multi-center case-control study (EPILIFT). Arthritis Res Ther 2010;12(5):R193. doi:10.1186/ar3164

33. Schistad EI, Bjorland S, Røe C, Gjerstad J, Vetti N, Myhre K, et al. Five-year development of lumbar disc degeneration-a prospective study. Skeletal Radiol 2019;48(6):871-879.

34. Nemoto Y, Matsuzaki H, Tokuhasi Y, Okawa A, Uematu Y, Nishimura T, et al. Histological changes in intervertebral discs after smoking and cessation: experimental study using a rat passive smoking model. J Orthop Sci 2006;11(2):191-197.
35. Nakahashi M, Esumi M, Tokuhashi Y. Detection of apoptosis and matrical degeneration within the intervertebral discs of rats due to passive cigarette smoking. PLoS One 2019;14(8):e0218298. doi:10.1371/journal.pone.0218298

36. Iwahashi M, Matsuzaki H, Tokuhashi Y, Wakabayashi K, Uematsu Y. Mechanism of intervertebral disc degeneration caused by nicotine in rabbits to explicate intervertebral disc disorders caused by smoking. Spine (Phila Pa 1976) 2002;27(13):1396-1401.

37. WHO global report on trends in tobacco smoking 2000-2025 1st edition. Available from: https://www.who.int/quantifying ehimpacts/publications/SHS.pdf

38. Barnoya J, Glantz SA. Cardiovascular effects of secondhand smoke nearly as large as smoking. Circulation 2005;111(20):2684-2698.

39. Reed RM, Dransfield MT, Eberlein M, Miller M, Netzer G, Pavlovich M, et al. Gender differences in first and secondhand smoke exposure, spirometric lung function and cardiometabolic health in the old order Amish: a novel population without female smoking. PLoS One 2017;12(3):e0174354. doi: 10.1371/journal. pone.0174354.

40. An HS, Silveri CP, Simpson JM, File P, Simmons C, Simeone FA, et al. Comparison of smoking habits between patients with surgically confirmed herniated lumbar and cervical disc disease and controls. J Spinal Disord 1994;7(5):369-373.

41. Knutsson B, Mukka S, Wahlström J, Järvholm B, Sayed-Noor AS. The association between tobacco smoking and surgical intervention for lumbar spinal stenosis: cohort study of 331,941 workers. Spine J 2018;18(8):1313-1317. 